\title{
THE EFFECT OF JOB SATISFACTION AND MOTIVATION ON EMPLOYEE ENGAGEMENT OF ADMINISTRATIVE STAFF OF BANDUNG STATE POLYTECHNIC
}

\author{
Andi Kari \\ Masters of Business Management Programme \\ School of Postgraduates Studies Bandung, Indonesian University of Education
}

\begin{abstract}
The research purposes to measure the level of job satisfaction and motivation and its influence on employee engagement PNS administrative staff of Bandung State Polytechnic, amounting to 293 employees spread across 15 units and work.

Determination by cluster random sampling technique method and samples were taken at random (random) that required 168 samples. Methods of research done by the survey, the data obtained by distributing questionnaires to the pegawaits. While the research model depicted in the form of the relationship between variables: Variable Satisfaction (X1) and work motivation (X2) on Employee Engagement ( $Y$ ).

The results generally show that the effect of the level of employee satisfaction "high", the level of employee motivation "very high", and the level of employee engagement "very high". Anova test results showed a difference in strata on aspects of job satisfaction, work motivation, and engagement of employees, but not significantly. Regression Test Results and Test $t$, partially shows that three variables affect each other positively. $F$ test results and the coefficient of determination shows that simultaneous job satisfaction and motivation influence employee engagement.
\end{abstract}

Keywords: Job Satisfaction, Work Motivation, Employee Engagement, Bandung State Polytechnic

\section{PENDAHULUAN}

Kurang atau lemahnya tingkat engagement pegawai yang ditandai dengan rendahnya tingkat dedikasi, loyalitas dan komitmen pegawai, disamping itu kurangnya rasa memiliki dan rasa bangga pegawai akan tempat dimana mereka bekerja juga merupakan suatu fenomena yang sering ditemukan oleh penulis.

Kepuasan kerja belum memberikan jaminan bahwa para pegawai akan bekerja secara maksimal, untuk itu kepuasan kerja perlu didukung oleh motivasi dari dalam diri pegawai itu sendiri karena kepuasan dan motivasi kerja merupakan salah satu faktor yang sangat penting untuk mendapatkan hasil kerja yang optimal.

Fenomena-fenomena yang terjadi dilapangan pada umumnya masih sering ditemukan adanya perilaku-perilaku pegawai yang menyimpang, misalnya pegawai yang selalu mengeluh tentang peraturan atau kebijakan yang ada, ini artinya bahwa pegawai tersebut merasakan tidak bebas dan merasa tidak puas atas aturan dan kebijakan yang berlaku, kemudian kecenderungan pegawai yang hanya mengutamakan catatan kehadiran melalui mesin absen (finger print) dan mereka berusaha untuk datang kerja sebelum waktu kerja normal, tetapi, alasan dibalik semua itu hanya semata-mata para pegawai takut mendapat surat peringatan karena dianggap mangkir atau tidak hadir (absen) manakala mereka tidak melaksanakan absensi kehadirannya sebagaimana mestinya, atau juga mendapat surat peringatan karena akumulasi waktu keterlambatan pegawai yang sudah melebihi batas toleransi yang telah diberikan oleh perusahaan. Fenomena yang lain seperti kebiasaan para pegawai yang selalu bergerombolan di tempat parkir kendaraan bermotor dan dengan bebasnya mereka berbicara, berdiskusi, bercanda dengan sesamanya, mereka tahu bahwa waktu pada 
saat itu mereka seharusnya sudah memulai aktivitas mereka sebagai pegawai tetapi mereka belum mau masuk ke tempat kerja kerjanya masing-masing. Kemudian masih adanya pegawai berkeliaran keluar masuk kantor pada saat-saat jam kerja karena dengan berbagai macam alasan, pegawai yang tidak mengerjakan atau belum mengerjakan tugas pokok yang menjadi tanggung jawab mereka serta kecenderungan pegawai untuk bermain game, facebook, chatting, dan sebagainya. Disisi lain adanya fenomena kecenderungan pegawai untuk selalu pulang tepat waktu (on time), ini dapat dilihat pada saat-saat waktu pulang kerja walaupun waktu di mesin absensi (finger print) belum menunjukkan waktunya untuk pulang, tetapi sebagian pegawai sudah bergerombolan dan antri untuk menanti waktu yang tepat melakukan absen pulang, ini memberi kesan bahwa pegawai tidak mau berlama-lama berada di kantor dan memberi kesan bahwa pegawai merasa tidak betah berada di kantor terlalu lama, mereka terkadang dengan sengaja menunda atau meninggalkan pekerjaan mereka saat itu hanya untuk pulang tepat pada waktunya.

Berdasarkan data dari Sub. Bag. Kepegawaian Politeknik Negeri Bandung untuk tahun 2012, dari 15 (lima belas) unit kerja mengalami penurunan kinerja pelayanan tenaga kependidikan dari jumlah nilai 46.00 pada tahun 2011 menjadi 43,6 untuk tahun 2012, sehingga ada selisih penurunan kinerja mencapai $(2,4)$ atau rata-rata penurunan nilai kinerja (16\%). Dengan kejadian hal semacam ini di lingkungan Politeknik Negeri Bandung memberi kesan dan gambaran bahwa fenomena-fenomena tersebut di atas berdampak negatif dan disinyalir menjadi penyebab rendahnya produktivitas kerja para pegawai.
Dampak yang lebih luas lagi, Hasil Penilaian Evaluasi Pelayanan Publik di Lingkungan Kementerian Pendidikan dan Kebudayaan (Kemendikbud) Tahun 2011, Nomor : 80442/A5.4/LL/2011, tanggal 15 September 2011, berdasarkan Peraturan Menteri PAN dan RB Nomor 7 tahun 2010 tentang Pedoman Penilaian Kinerja Unit Pelayanan Publik, dengan aspek yang dinilai yaitu: Visi, Misi, dan Motto Pelayanan; Sistem dan Prosedur Pelayanan; Sumber Daya Manusia Pelayanan; Sarana dan Prasarana Pelayanan. Berdasarkan Berita Acara Penilaian dari setiap aspek yang dinilai, total nilai yang diperoleh Politeknik Negeri Bandung adalah 89,42. Selain keempat aspek tersebut, ada aspek lain yang juga menjadi penilaian tim yaitu aspek Indeks Kepuasan Masyarakat (IKM) berdasarkan Keputusan Menteri Pendayagunaan Aparatur Negara Nomor : KEP/25/ M.PAN/2/2004 tentang Pedoman Umum Penyusunan Indeks Kepuasan Masyarakat Unit Pelayanan Instansi Pemerintah.

Unsur-unsur Indeks Kepuasan Masyarakat sebagaimana telah ditetapkan dalam Keputusan Men.PAN Nomor : 63/KEP/M.PAN/7/2003, yang kemudian dikembangkan menjadi 14 unsur yang relevan, valid dan realibel, nilai yang diperoleh Politeknik Negeri Bandung adalah 66.98. Sehingga total dari seluruh aspek penilaian Politeknik Negeri Bandung mendapat nilai 80,44 (kriteria : baik) dari skala nilai 100 dan menempatkan Politeknik Negeri Bandung berada pada posisi diurutan kedelapan dari empat belas instansi publik yang diukur kinerjanya oleh Kementerian Pendidikan dan Kebudayaan Republik Indonesia.

Berdasarkan tabel di atas, jika ditarik suatu kesimpulan bahwa dari ke empat aspek yang dinilai secara keseluruhan sudah baik (nilai 89,42), tetapi tidak diimbangi dengan aspek lainnya yakni aspek Indeks Kepuasan Masyarakat (IKM) yang hanya dengan 
memperoleh nilai 66,98. Nilai ini jauh dari harapan Politeknik Negeri Bandung dan nilai ini masih dianggap kurang bahkan dianggap terlalu rendah jika dibanding dengan perguruan tinggi yang ada. Nilai aspek Indeks Kepuasan Masyarakat (IKM) tidak berdampak positif dan signifikan dibandingkan dengan nilai aspekaspek lainnya. Apalagi jika dibandingkan dengan motto Politeknik Negeri Bandung yang tertulis: "Sampaikan keperluan Anda dengan cepat, sopan, dan taat aturan. Kami akan melayani dengan cepat, sopan, dan taat aturan". Nilai Indeks Kepuasan Masyarakat (IKM) ini seakanakan memberi arti bahwa tingkat kepercayaan masyarakat baik masyarakat kampus maupun masyarakat di luar kampus terhadap pelayanan di Politeknik Negeri Bandung masih rendah.

Keberadaan pegawai yang mempunyai engagement tinggi tentunya akan memberikan dampak positif bagi perusahaan/organisasi dalam menjalankan roda bisnisnya, pegawai yang engage akan memberikan hasil yang lebih baik dari yang diharapkan, pegawai mempunyai rasa memiliki dan komit kepada perusahaan, berkinerja tinggi serta konsisten, banyak ide baru yang dikemukakan dan selalu berinovasi serta selalu mendorong kearah efisiensi, efektif dan meningkatkan produktivitas serta bekerja tekun, ikhlas atas tugas yang diberikan perusahaan kepada mereka, serta mampu beradaptasi terhadap segala perubahan dan mereka tidak alergi akan perubahan tersebut.

Penelitian ini merupakan lanjutan dan pengembangan dari penelitian yang telah dilakukan oleh tim survei sebelumnya terhadap kepuasan dan motivasi kerja pegawai Politeknik Negeri Bandung. Untuk penelitian kali ini, penulis ingin mengembangkan hubungan kepuasan dan motivasi kerja terhadap engagement pegawai khususnya tenaga kependidikan. Penelitian dilakukan di Politeknik Negeri Bandung yang merupakan salah perguruan tinggi yang menyelenggarakan pendidikan tinggi Diploma III dan Diploma IV. esia dan kemaslahatan umat manusia.
Tuntutan masyarakat akan kebutuhan proses belajar mengajar di perguruan tinggi yang berkualitas dan unggul saat ini semakin meningkat dan beragam. Perguruan tinggi memegang peranan penting bagi kemajuan suatu bangsa, dan juga perguruan tinggi dituntut untuk berperan tidak hanya sekedar untuk memenuhi permintaan akan tenaga kerja saja atau hanya untuk memenuhi perkembangan ilmu pengetahuan dunia modern, namun lebih berperan sebagai pendorong bagi perkembangan ilmu pengetahuan itu sendiri. Disamping itu dengan berkembangannya ilmu pengetahuan dan teknologi, permintaan akan tenaga kerja yang kompetitif dengan tingkat edukasi yang tinggi serta memiliki keahlian juga semakin meningkat. $\mathrm{Hal}$ ini merupakan peluang bagi perguruan tinggi untuk membuktikan tingkat kualitas dan keunggulan daya saingnya.

Persaingan antar institusi pendidikan tinggi baik yang berstatus sebagai perguruan tinggi negeri maupun swasta semakin kompetitif. Persaingan ini akan semakin lebih ketat lagi dengan adanya kebijakan Pemerintah melalui Kementerian Pendidikan dan Kebudayaan Republik Indonesia yang menjadikan beberapa perguruan tinggi termasuk politeknik yang berada di daerah yang beralih status dari perguruan tinggi swasta menjadi perguruan tinggi negeri.

Persaingan ini menuntut upaya yang serius bagi para pengelola atau pemimpin institusi pendidikan tinggi untuk menerapkan strategi bisnis yang tepat dan logis agar kelangsungan hidup institusi pendidikan tinggi tersebut tetap terjamin dan proses belajar mengajar tetap terlaksana dengan baik. Keberhasilan dalam persaingan bisnis tidak lepas dari kualitas lulusannya yang memenangkan persaingan dalam mendapatkan pekerjaan. Semakin cepat dan singkat waktu para alumni untuk mendapatkan pekerjaan semakin berkualitas dan punya daya saing bagi perguruan tinggi tersebut. 
Disisi lain dengan adanya lonjakan peningkatan pendaftar calon mahasiswa baru untuk mengikuti pendidikan di Politeknik Negeri Bandung sangat berdampak pada semua aspek, salah satunya adalah dengan peningkatan pelayanan yang harus dikelola 3 secara profesional dan berkualitas kepada para mahasiswa khususnya dan kepada masyarakat kampus dan masyarakat diluar kampus, karena dengan meningkatnya peminat calon mahasiswa baru menggambarkan begitu tingginya harapan dan kepercayaan masyarakat kepada Politeknik Negeri Bandung. Peningkatan pendaftaran calon mahasiswa baru ini untuk saat ini belum mampu mengakomodasikan semua keinginan pendaftar untuk mengikuti pendidikan di Politeknik Negeri Bandung karena adanya keterbatasan sarana dan prasarana. Hal ini dapat dilihat dari perbandingan antara jumlah pendaftar dengan yang diterima serta kemampuan daya tampung di Politeknik Negeri Bandung untuk menerima calon mahasiswa baru sebagai mahasiswa baru yang mempunyai kesempatan untuk menikmati pendidikan di Politeknik Negeri Bandung. Sebagaimana dapat dilihat pada tabel 1 di bawah ini :

\section{Tabel 1}

Jumlah Pendaftar Calon Mahasiswa Baru Polikteknik Negeri Bandung Tahun Akademik 2008/2009 - 2012/2013

\begin{tabular}{|c|c|c|c|c|}
\hline Tahun & Pendaftar & Diterima & Persentase & $\begin{array}{c}\text { Rasio } \\
\text { Kompetisi } \\
\text { tiap Prodi }\end{array}$ \\
\hline $2008 / 2009$ & 5.076 & 1.493 & $29.41 \%$ & $1: 3.40$ \\
\hline $2009 / 2010$ & 5.818 & 1.508 & $25.92 \%$ & $1: 3.86$ \\
\hline $2010 / 2011$ & 7.377 & 1.483 & $20.10 \%$ & $1: 4.97$ \\
\hline $2011 / 2012$ & 8.940 & 1.552 & $17.36 \%$ & $1: 5.76$ \\
\hline $2012 / 2013$ & 12.550 & 1.833 & $14.61 \%$ & $1: 6.85$ \\
\hline
\end{tabular}

Sumber: Politeknik Negeri Bandung, 2013

Data tersebut di atas dapat ditarik suatu kesimpulan bahwa jumlah peminat peserta yang ingin mengikuti pendidikan di Politeknik Negeri Bandung selalu menunjukkan adanya peningkatan. Untuk Tahun Akademik 2012/2013 terjadi lonjakan peminat peserta pendaftar dari tahun sebelumnya, tetapi peningkatan ini tidak signifikan bila dibandingkan dengan jumlah propinsi yang ada di Indonesia. Jumlah peminat peserta pendaftar untuk lima tahun terakhir selalu didominasi oleh calon peserta pendaftar dari Propinsi Jawa Barat. Untuk Tahun Akademik 2012/2013 jumlah peserta pendaftar dari Propinsi Jawa Barat sebanyak 11.318 (90,18 \%) peserta.

Sedangkan untuk jumlah peminat peserta yang ingin mengikuti pendidikan di Politeknik Negeri Bandung dari seluruh kabupaten dan kota di wilayah Propinsi Jawa Barat, Kota Bandung dengan jumlah peserta peminat yang paling banyak yang berjumlah 3.916 (34,60\%) peserta, kemudian disusul daerah Kota Cimahi sebanyak 1.075 (9,50\%) peserta dan daerah Kabupaten Garut sebanyak 1.041 (9,20\%) peserta.

Kemungkinan salah satu alasan para calon mahasiswa baru khususnya para peminat peserta pendaftar dari Kota Bandung untuk memilih Politeknik Negeri Bandung sebagai tempat mereka mengikuti pendidikan tinggi adalah faktor lokasi kampus yang dekat dengan lokasi tempat tinggal.

Indikasi ini memberikan sinyal kepada Politeknik Negeri Bandung untuk terus mengembangkan dan meningkatkan kualitas dan daya saing pendidikannya sehingga keberadaan Politeknik Negeri Bandung tidak hanya dikenal hanya di wilayah Propinsi Jawa Barat saja, tetapi harus menjangkau wilayahwilayah lain yang jauh lebih luas lagi di luar Propinsi Jawa Barat, sehingga ada peningkatan signifikan baik dari jumlah peminat peserta pendaftar maupun dari jumlah mahasiswa daerah lainnya di luar Propinsi Jawa Barat yang mengikuti pendidikan di Politeknik Negeri Bandung

Dengan adanya peningkatan jumlah peserta peminat pendaftar maupun jumlah mahasiswa dari daerah di luar Propinsi Jawa Barat mengindikasikan bahwa Politeknik 
Negeri Bandung dianggap mampu bersaing dengan perguruan tinggi lainnya, berkualitas dan unggul serta memiliki daya saing, sehingga masyarakat Indonesia percaya akan kualitas pendidikan Politeknik Negeri Bandung. Untuk membangun keunggulan bersaing tersebut sebagaimana dinyatakan dalam visi "menjadi institusi yang unggul dan terdepan dalam pendidikan vokasi yang inovatif dan adaptif terhadap perkembangan ilmu pengetahuan dan teknologi terapan", Politeknik Negeri Bandung harus didukung oleh sumber daya manusia yang berkualitas, kompeten, berkinerja tinggi, serta memiliki motivasi dan dedikasi tinggi. Untuk itu perlu dukungan dan komitmen bersama dari seluruh pegawai baik tingkat pimpinan, staf pendidik (dosen) dan staf kependidikan (non dosen). Berbagai cara dan strategi telah dilakukan oleh Politeknik Negeri Bandung dalam upaya meningkatkan kualitas kinerjanya agar memiliki keunggulan kompetitif, misalnya dengan menerapkan dan mengembangkan manajemen pendidikan yang profesional, mendorong pegawainya untuk bekerja secara profesional dan pengelolaan sumber daya yang tepat serta meningkatkan kinerja pegawainya dengan memperhatikan aspek kepuasan dan aspek motivasi pegawai.

Seiring dengan perkembangan zaman, ditandai dengan berkembangnya ilmu pengetahuan dan teknologi serta semakin tingginya persaingan di era global ini, dan semakin kompetitifnya tuntutan kebutuhan manusia, rasanya faktor kepuasan dan motivasi kerja belum cukup memberikan gambaran dan jaminan akan tingkat dedikasi dan loyalitas serta kinerja pegawai. Karena bisa saja seorang pegawai yang memiliki kepuasan tinggi, justru tidak termotivasi untuk menunjukkan kinerja yang terbaik atau sebaliknya pegawai yang memiliki motivasi tinggi belum tentu merasa puas sehingga bagi perusahaan ini merupakan suatu kendala dalam proses pencapaian tujuannya. Untuk itu pada saat ini disamping faktor-faktor tersebut di atas juga dibutuhkan pegawaipegawai yang mempunyai engagement.

Perumusan masalah penelitian difokuskan untuk menjawab pertanyaan-pertanyaan terhadap permasalahan seperti di bawah ini :

1. Bagaimana tingkat kepuasan kerja pegawai tenaga kependidikan Politeknik Negeri Bandung ?

2. Bagaimana tingkat motivasi kerja pegawai tenaga kependidikan Politeknik Negeri Bandung ?

3. Bagaimana tingkat engagement pegawai tenaga kependidikan Politeknik Negeri Bandung ?

4. Adakah pengaruh tingkat kepuasan kerja pegawai terhadap tingkat engagement pegawai tenaga kependidikan Politeknik Negeri Bandung?

5. Adakah pengaruh tingkat motivasi pegawai terhadap tingkat engagement pegawai tenaga kependidikan Politeknik Negeri Bandung ?.

Sedangkan tujuan penelitian untuk mengetahui dan menganalisis serta memberikan gambaran yang detail tentang faktor-faktor kepuasan dan motivasi kerja terhadap tingkat engagement pegawai tenaga kependidikan Politeknik Negeri Bandung, dengan tujuan rincian penelitian adalah untuk mengetahui :

1. Pengaruh tingkat kepuasan kerja khususnya pada aspek pekerjaan, supervisi, kesejahteraan, promosi, dan hubungan kerja terhadap engagement pegawai tenaga kependidikan Politeknik Negeri Bandung.

2. Pengaruh tingkat motivasi kerja khususnya aspek prestasi, pengakuan, pekerjaan, tanggung jawab, dan pengembangan terhadap engagement pegawai tenaga kependidikan Politeknik Negeri Bandung.

3. Pengaruh tingkat kepuasan kerja dan motivasi kerja pegawai terhadap 
engagement pegawai tenaga kependidikan

Politeknik Negeri Bandung

\section{KERANGKA PEMIKIRAN \& HIPOTESIS}

Berdasarkan hasil penelitian terhadap kepuasan dan motivasi pegawai dilingkungan
Politeknik Negeri Bandung tentang korelasi antara kepuasan dan motivasi kerja pegawai menunjukan adanya hubungan yang positif dan signifikan, dan hubungan ini dapat dilihat pada gambar 1 di bawah ini :

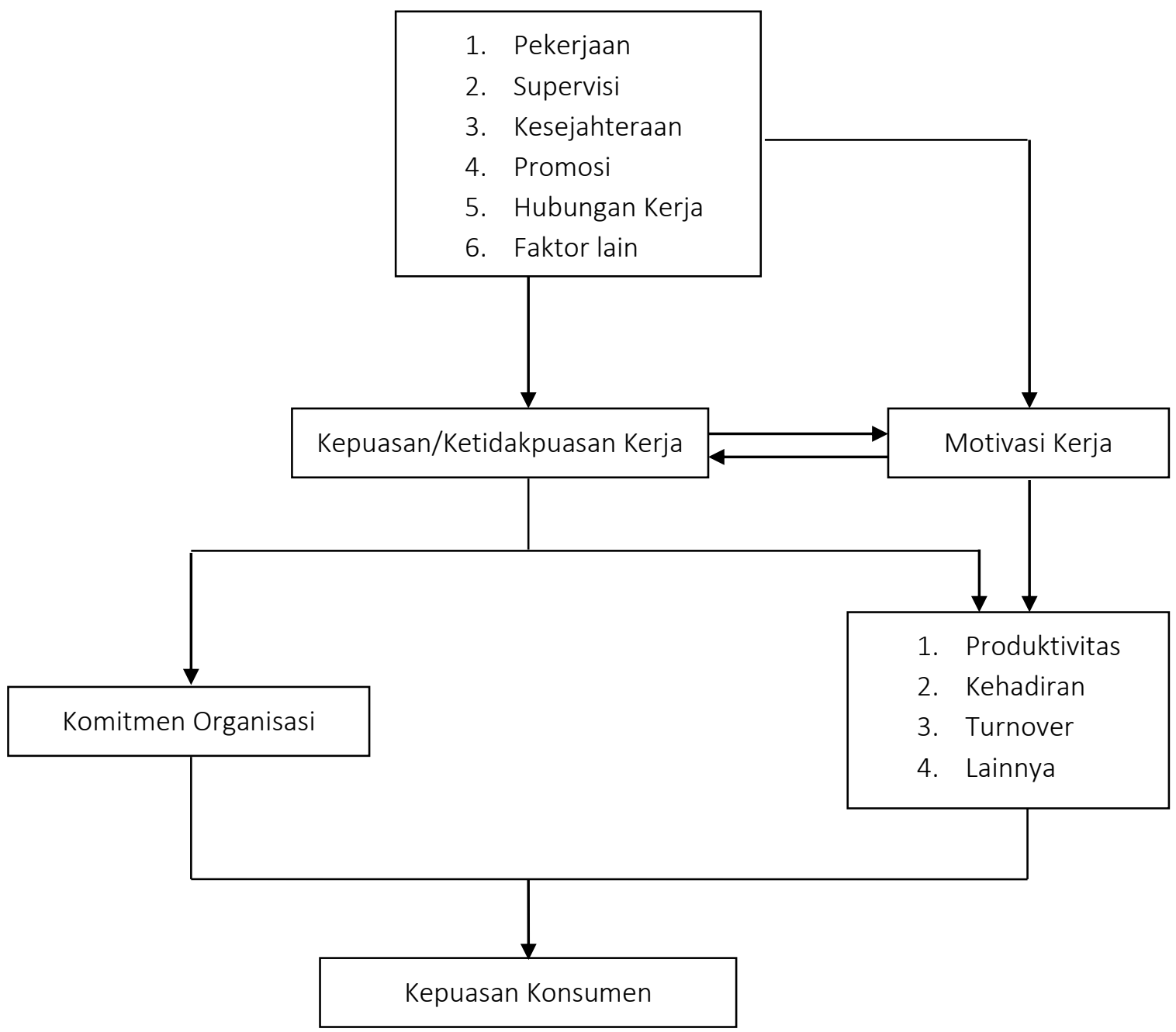

Gambar 1

Model Hubungan Kepuasan dan Motivasi Kerja

Sumber: Laporan Akhir Tim Survei Kepuasan Kerja POLBAN (2011:9)

Dari gambar tersebut di atas hubungan antara variabel kepuasan dan motivasi berkisar 0.5 , tetapi secara total variabel kepuasan kerja mempunyai hubungan yang relatif kuat dengan variabel motivasi kerja ( $r>0,7)$. Hasil uji korelasi dapat dilihat pada tabel 2 di bawah ini : 
Tabel 2

\section{Korelasi Kepuasan Kerja dengan Motivasi} Kerja

\begin{tabular}{|c|l|c|}
\hline No & \multicolumn{1}{|c|}{ Variabel } & Motivasi Kerja \\
\hline 1 & Pekerjaan & 0,644 \\
\hline 2 & Supervisi & 0,600 \\
\hline 3 & Kesejahteraan & 0,460 \\
\hline 4 & Promosi & 0,540 \\
\hline 5 & Hubungan Kerja & 0,584 \\
\hline 6 & Total Kepuasan Kerja & 0,736 \\
\hline
\end{tabular}

Sumber: Laporan Akhir Tim Survei Kepuasan Kerja POLBAN 2011:24)

Hasil ini mengindikasikan bahwa semakin puas karyawan terhadap kerjanya semakin tinggi motivasi kerjanya; atau sebaliknya, semakin termotivasi karyawan untuk bekerja akan semakin puas mereka dengan pekerjaannya Disamping itu, penelitian lain menjelaskan bahwa employee engagement pada diri pegawai sangat mempengaruhi kualitas kerja, meningkatkan kepuasan kerja dan menurunkan turn over, karena pegawai memiliki keterikatan emosi tinggi pada perusahaan dimana pegawai tersebut bekerja.

Gallup Consulting membandingkan tingkat engagement pegawai di beberapa perusahaan dimana hasilnya menyatakan bahwa pegawai di perusahaanperusahaan yang word class mencapai 67\% jauh lebih tinggi dibandingkan dengan perusahaan biasa.

Sedangkan tingkat pegawai yang tergolong dalam non egaged dan actively disengaged untuk perusahaanperusahaan word class sangat kecil jumlahnya jika dibandingkan dengan perusahaan biasa. Disamping itu, Gallup Consulting dalam http://michaeladryanto. wordpress.com [April 17,211] mencatat tingkat employee engagement tinggi terbukti memiliki efektivitas kinerja yang juga tinggi. Produktivitas mereka 70\% lebih tinggi, nilai pelayanan pelanggan mereka $86 \%$ lebih bagus, profitabilitas mereka mencapai $44 \%$ lebih tinggi, catatan keselamatan kerja mencpai $78 \%$ lebih baik, dan tingkat turn over mereka lebih rendah sekitar $70 \%$.

Sedangkan Harter, et.,al. (2003:43-44) mengemukakan hasil penelitiannya dalam perusahaaan, unit bisnis yang mencatat tingkat employee engagement tinggi terbukti memiliki efektivitas kinerja yang tinggi pula. Tingkat ratarata keberhasilan 56\% pada tingkat loyalitas pelanggan, 50\% probilitas lebih tinggi, 38\% produktivitas, $27 \%$ profitabilitas lebih tinggi, 68\% keselamatan kerja mereka lebih baik, dan tingkat turnover mereka $70 \%$ lebih rendah.

Sarah Cook perusahaan yang memiliki tingkat employee engagement yang lebih tinggi akan mampu mengalahkan pesaing mereka dari segi profitabilitas. Selanjutnya, Cook (2008) memaparkan beberapa hasil penelitianpenelitian sebelumnya seperti yang pernah dilakukan oleh perusahaan jasa profesional ISRTowers Perrin mampu mengalahkan pesaing mereka dalam hal kinerja dan bidang profitabilitas sebesar $17 \%$. Kemudian pada bulan Agustus 2005, hasil penelitian ISR-Tower Perin menunjukkan bahwa perusahaan dengan tingkat employee engagement yang lebih rendah mengalami penurunan profit sebesar $1,38 \%$ dan penurunan margin sebesar 2,01\% dalam 36 bulan. Perusahaan dengan employee engagement menengah mengalami peningkatan profit sebesar 2,06\% dan peningkatan margin sebesar 3,74\% dalam 36 bulan. Sedangkan hasil yang dilakukan oleh Harry Group dalam Dwi Idawati, dkk, (2010:16) menemukan bahwa organisasi jasa dengan pegawai yang terengaged mengalami peningkatan produktivitas sebesar $43 \%$.

Hasil penelitian lain secara fakta adanya hubungan antara employee engagement dan hasil bisnis yang melebihi kepuasan dan loyalitas. Sebagaimana pendapat Dwi Idawati,dkk (2010:15), IES (Institute for Employment Studies) dalam penelitiannya melalui IES Survei tahun 2003, didapatkan bahwa kepuasan kerja merupakan salah satu 
pemicu terciptanya engagement. Sehingga dapat disimpulkan bahwa kepuasan pegawai berpengaruh terhadap engagement pegawai. Pendapat lain juga diungkapkan oleh Harter et.al., (2002) bahwa Employee Engagement dapat tercipta dari kepuasan kerja karyawan. Dalam pandangan ini, antara engagement dengan kepuasan kerja memiliki hubungan langsung.

Para peneliti terdahulu menyatakan bahwa

employee engagement memberi dampak pada perilaku individu seperti peningkatan kualitas kerja, kepuasan kerja meningkat, tingkat ketidak hadiran pegawai cenderung menurun serta dapat menekan angka pegawai yang pindah pekerjaan. Pegawai yang memiliki tingkat derajat engagement tinggi akan tumbuh rasa memiliki dan ikatan emosional antara pegawai dengan perusahaan sehingga memacu semangat pegawai untuk bekerja secara optimal.

Development Dimension International. Inc., pada tahun 2006 mengungkapkan bahwa hasil penelitian mereka terhadap tingkat employee engagement dan kinerja pegawai menunjukkan bahwa ketika skor engagement tinggi, maka karyawan akan lebih puas terhadap pekerjaan, kemudian tingkat keinginan untuk meninggalkan pekerjaan menjadi rendah dan pegawai akan menjadi produktif. Ini artinya bahwa employee engagement memberikan hasil positif terhadap perilaku pegawai.

Berdasarkan kajian teori dan hasil penelitian para ahli mengenai variabel-variabel yang diteliti dalam penelitian ini, maka oleh penulis akan dirumuskan hubungan teoritis antar variabel-variabel seperti kepuasan pegawai, motivasi pegawai, dan engagement pegawai dan penulis berasumsi bahwa kepuasan pegawai berdampak langsung dan memberikan hasil positif dan signifikan terhadap engagement pegawai sebagaimana hasil penelitian sebelumnya. Karena pegawai yang puas disamping adanya ikatan emosional juga akan memberikan segala kemampuannya diluar apa yang diharapkan oleh perusahaan.

Pengaruh motivasi pegawai terhadap engagement pegawai juga berdampak positif dan signifikan, karena pegawai yang mempunyai motivasi tinggi akan termotivasi untuk bekerja secara maksimal dan ini akan berdampak positif terhadap engagement pegawai.

Menurut Institute for Employement Studies (IES) bagian-bagian seperti : employees are involved in decision making, managers listen to employees, employees have the oppurtunity to develop their jobs, good suggestions are acted upon, employees feel able to voice rheir opinions, senior managers show employees that they values them, dan employee demonstrated concern about employees health and well being merupakan bagian yang sangat penting dari engagement. Bagian-bagian tersebut dapat dilihat pada engagement model seperti gambar 2 di bawah ini :

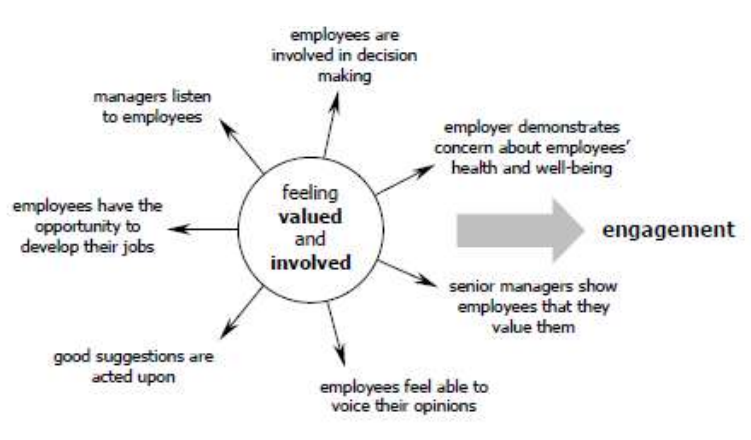

\section{Gambar 2 \\ Engagement Model}

Sumber: D. Robinson, S. Perryman, S. Hayday (2004:22)

Selanjutnya Institute for Employment Studies (IES) mendiagnosa bagian-bagian (tools) dari egagement sebagai penggerak (drivers) sebagaimana gambar 3 di bawah ini : 


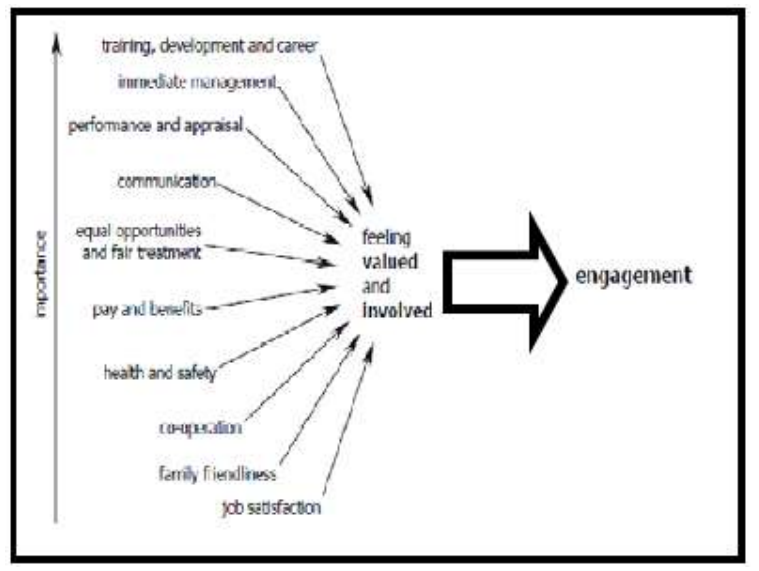

\section{Gambar 3}

The Drivers of Employee Engagement

Sumber: D. Robinson, S. Perryman, S. Hayday (2004:23)

Berdasarkan karakteristik variabel dan berdasarkan kajian konsep-konsep/teoriteori/dalil-dalil/hukum-hukum/model-

model/rumus-rumus utama dan turunannya dalam bidang yang dikaji, maka model hubungan variabel penelitian dapat digambarkan sebagaimana gambar 4 dibawah ini :

\section{Gambar 4}

\section{Model Hubungan Variabel Penelitian}

Keterangan :

$X_{1}=$ Kepuasan Kerja

$X_{2}=$ Motivasi Kerja

$\mathrm{Y}=$ Engagement Pegawai

Dalam penelitian ini menggunakan hipotesis hubungan (asosiatif) yang menunjukan tentang hubungan antara variabel-variabel. Berdasarkan kerangka pemikiran yang oleh penulis gambarkan dalam bentuk model penelitian, maka dapat dibuat suatu hipotesis hubungan (asosiatif) yang merukapan dugaan tentang adanya hubungan antara variabel dalam populasi yang akan diuji melalui hubungan antar variabel dalam sampel yang diambil dari populasi tersebut :
1. Tingkat kepuasan kerja pegawai berpengaruh positif terhadap engagement pegawai tanaga kependidikan.

2. Tingkat motivasi kerja pegawai berpengaruh positif terhadap engagement pagawai tenaga kependidika.

\section{METODE PENELITIAN}

Metode penelitian yang digunakan adalah metode survei dengan tujuan deskriptif explanatory yang menggunakan analisis dan jenis data kuantitatif. Model penelitian digambarkan dalam suatu bentuk yang bertujuan memperjelas hubungan antara variabel yang diteliti. Model penelitian ini terdiri dari dua variabel independen yaitu Kepuasan Kerja $\left(X_{1}\right)$ dan Motivasi Kerja $\left(X_{2}\right)$ serta satu variabel dependen yaitu Engagement Pegawai (Y).

Dalam penelitian ini penulis memberikan asumsi tentang metode penelitian tersebut yaitu suatu metode yang tujuan penelitiannya ialah untuk menggambarkan keadaan yang berlaku sekarang di Politeknik Negeri Bandung. Pada bagian ini, peneliti mengajukan kerangka pemikiran teoritis yang diambil berdasarkan hasil telaah pustaka dan penelitian terdahulu.

Pada penelitian ini, penulis mempergunakan tiga variabel, masing-masing dua variabel independen yakni : Kepuasan Kerja $\left(X_{1}\right)$ dan Motivasi Kerja $\left(X_{2}\right)$ Sedangkan untuk variabel dependen adalah Engagement Pegawai (Y).

Agar tidak terjadi perbedaan persepsi tentang pengertian dari semua variabel yang akan diteliti, maka perlu kiranya diberikan definisi operasional variabel dengan indikatorindikator sebagai berikut :

a. Kepuasan Kerja,

Adalah situasi dan kondisi pegawai tentang perasaan yang dirasakan terhadap hasil pekerjaan yang telah dicapai atau yang telah dikerjakan. Instrumen yang dipakai dalam mengukur kepuasan kerja ini adalah dengan 
memperhatikan elemen-elemen sebagaimana yang dijelaskan oleh Rue and Byats (2003) dalam Laporan Akhir Tim Survei Kepuasan Kerja Politeknik Negeri Bandung (2011:4) yang menyatakan bahwa kepuasan kerja dapat diukur dari lima faktor utama seperti: Nature of work (include working condition), Supervision, Monetary Benefit, Promotion Opportunity, Relation with co-workers.

\section{HASIL DAN PEMBAHASAN}

Sesuai dengan tujuan penelitian pengujian hipotesis untuk melihat sifat dan besaran pengaruh setiap subvariabel penerapan sistem administrasi perpajakan modern $(X)$ yang terdiri dari modernisasi struktur organisasi $\left(X_{1}\right)$, prosedur organisasi $\left(X_{2}\right)$, strategi organisasi $\left(X_{3}\right)$ dan budaya organisasi $\left(X_{4}\right)$ terhadap kepatuhan Wajib Pajak (Y). Setelah data ordinal diubah menggunakan metode successive interval menjadi data skala, dengan bantuan apliksasi SPSS, hubungan antar variabel tersebut akan dianalisis dalam paradigma penelitian jalur dengan menggunakan analisis korelasi dan analisis regresi.

Hasil analisis korelasi Pearson menunjukkan bahwa setiap subvariabel bebas sistem

\section{Tabel 3}

Matriks Hasil Analisis ANOVA Kepatuhan WP

Unstandardized

\section{Model} Coefficients

\begin{tabular}{crr} 
& \multicolumn{1}{c}{ B } & Std. Error \\
\hline (Constant) & 93.119 & 26.852 \\
\hline X1 & .551 &. \\
\hline Table 3, & diketaui & bahwa
\end{tabular}

Berdasarkan Table 3, diketaui bahwa
sistem administrasi perpajakan modernisasi, meliputi: struktur organisasi, prosedur organisasi, strategi organisasi, dan budaya organisasi secara parsial berpengaruh secara signifikan terhadap kepatuhan ( $p=.000 ; \alpha=.05$ ).

Demikian halnya subvariabel bebas sistem administrasi perpajakan modernisasi, meliputi: struktur organisasi, prosedur organisasi, strategi administrasi perpajakan modern yaitu modernisasi struktur organisasi, prosedur organisasi, strategi organisasi, dan budaya organisasi berkorelasi secara signifikan dengan variabel kepatuhan $(p=.000 ; \alpha=.05)$. Seperti terlihat pada Tabel 1.

Tabel 1

Matriks Hasil Analisis Korelasi

\begin{tabular}{rrrrrr}
\hline & $Y$ & $X 1$ & $X 2$ & $X 3$ & $X 4$ \\
\hline$Y$ & 1.000 & .667 & .618 & .777 & .686 \\
\hline$X 1$ & .667 & 1.000 & .639 & .693 & .339 \\
\hline$X 2$ & .618 & .639 & 1,000 & .697 & .714 \\
\hline$X 3$ & .777 & .693 & .697 & 1,000 &, 649 \\
\hline$X 4$ & .686 & .339 & .714 &, 649 & 1,000 \\
\hline
\end{tabular}

Sumber: Hasil SPSS, $(p=.000 ; \alpha=.05)$

Hasil analisis regresi dengan pendekatan ANOVA dapat diketahui bahwa secara umum subvariabel administrasi perpajakan membentuk model regresi linear berganda secara sangat signifikan terhadap kepatuhan Wajib Pajak. Jika diuji besaran setiap koefisien regresinya akan diperoleh hasil seperti yang terlihat dalam Tabel 2. 


\begin{tabular}{ccccrr}
\hline Subvar & $\boldsymbol{r}$ & $\boldsymbol{p}$ & $\mathrm{R}$ Square & $\mathrm{t}$ & $\begin{array}{c}\mathrm{p}- \\
\text { value }\end{array}$ \\
\hline $\mathrm{X} 1$ & 0.667 & 0.267 & 0.178089 & 12.381 & .000 \\
\hline $\mathrm{X} 2$ & 0.618 & 0.314 & 0.194052 & 9.378 & .000 \\
\hline $\mathrm{X} 3$ & 0.777 & 0.367 & 0.285159 & 14.113 & .018 \\
\hline $\mathrm{X} 4$ & 0.686 & 0.246 & 0.168756 & 11.333 & .000 \\
\hline $\mathrm{X}$ & & & 0.826056 & $\mathrm{~F}=132.67$ & .000 \\
\hline
\end{tabular}

Sumber: Resume Hasil SPSS

Keterangan:

$X 1=$ Modernisasi Struktur Organisasi

X2 = Modernisasi Prosedur Organisasi

X3 = Modernisasi Strategi Organisasi

X4=Modernisasi Budaya Organisasi

$Y=$ Kepatuhan Wajib Pajak

Hasil penelitian ini menunjukkan:

1. Pengaruh modernisasi struktur organisasi, prosedur organisasi, strategi organisasi, dan budaya organisasi secara simultan terhadap kepatuhan Wajib Pajak mencapai $82,61 \%$. Sisanya dipengaruhi oleh variable lain yang tidak diteliti dalam penelitian ini, yaitu $17,39 \%$.

2. Pengaruh Modernisasi Struktur Organisasi secara parsial terhadap Kepatuhan Wajib Pajak sebesar 17,81\%

3. Pengaruh modernisasi prosedur organisasi secara parsial terhadap kepatuhan Wajib Pajak sebesar 19,41\%

4. Pengaruh modernisasi strategi organisasi secara parsial terhadap kepatuhan Wajib Pajak sebesar 28,52\%.

5. Pengaruh modernisasi budaya organisasi secara parsial terhadap kepatuhan Wajib Pajak sebsar $16,88 \%$.

Dengan demikian implementasi sistem administrasi perpajakan modern yang terdiri dari modernisasi struktur organisasi, modernisasi prosedur organisasi, modernisasi strategi organisasi, dan modernisasi budaya organisasi secara langsung maupun tidak langsung memiliki pengaruh yang signifikan terhadap kepatuhan Wajib Pajak, yaitu sebesar $82,61 \%$.
Tanggapan Wajib Pajak atas penerapan sistem administrasi perpajakan modern secara umum setuju. Dukungan ini dapat dilihat dari hasil wawancara didapatkan informasi bahwa Wajib Pajak yang perusahaannya memiliki banyak cabang, berharap sistem administrasi perpajakan modern segera diterapkan pada semua KPP karena Wajib Pajak menerima pelayanan yang berbeda dari KPP lain yang belum menerapkannya.

Hasil pengujian hipotesis menunjukkan adanya korelasi positif di antara tiap subvariabel penerapan sistem administrasi perpajakan modern dan variabel kepatuhan Wajib Pajak. Korelasi tersebut signifikan. hasil pengujian hipotesis selanjutnya menunjukkan adanya pengaruh yang signifikan dari tiap subvariabel penerapan sistem administrasi perpajakan modern terhadap kepatuhan Wajib Pajak baik secara parsial maupun secara simultan.

Penerapan modernisasi prosedur organisasi dalam parktiknya terutama berupa penunjukkan Account Representative yang merupakan kegiatan utama program pengembangan Pelayanan Prima dimana dalam pelaksanaannya mendapatkan tanggapan positif baik dari Pegawai Pajak maupun Wajib Pajak. Tugas Account Representative dalam menginformasikan perubahan ketentuan perpajakan dan interpretasinya serta membantu Wajib Pajak dalam memperoleh penegasan dan konfirmasi atas permasalahan perpajakan hampir selalu terlaksana.

Hasil wawancara dapat diketahui bahwa pelaksanaan tugas tersebut tidak optimal dikarenakan masih kurangnya akses informasi atas peraturan baru, Wajib Pajak juga mengharapkan Account Representative memiliki pemahaman yang luas atas jenis usaha Wajib Pajak. Konsolidasi internal dan laporan internal rutin banyak terhambat oleh ketiadaan prosedur kerja KPP modern, serta hasil obeservasi dan wawancara, juga dapat diketahui belum tersusunnya ukuran dan pengukuran 
serta standar kinerja pelayanan dan pengawasan.

Penggunaan media elektronik terutama dalam pelaporan Surat Pemberitahuan (SPT) dengan e-SPT dan e-Filing dapat meningkatkaan produktivitas dan mengurangi compliance cost Wajib Pajak, tanggapan positif atas e-SPT dan eFiling.

Wajib Pajak pada dasarnya setuju bahwa tiap hambatan teknis dalam e-SPT akan dibantu penyelesaiannya, hambatan tersebut menurut Wajib Pajak antara lain berupa penggunaan eSPT yang dirasakan terburu-buru dan kurang disosialisasikan, serta masih ditemukan masalah dalam transfer dan upload data.

Penerapan struktur organisasi antara lain berkaitan dengan penyusunan organisasi berdasarkan fungsi, kegiatan dalam program meningkatkan produktifitas aparat perpajakan ini mendapatkan tanggapan yang positif dari Pegawai Pajak, dimana penyusunan organisasi berdasarkan fungsi hampir selalu memudahan jalur penyelesaian pelayanan dan pemeriksaan menjadi tidak kaku/ketat dengan prinsip orientasi hasil.

Pengembangan Sistem Informasi Perpajakan (SIP) dengan pendekatan fungsi menjadi Sistem Administrasi Perpajakan Terpadu (SAPT) yang dikendalikan oleh case management system dalam workflow system hampir selalu diterapkan sesuai dengan fungsinya. Penyempurnaan Sistem Administrasi Perpajakan Terpadu (SAPT) terus dilakukan dengan dilengkapi berbagai modul yang mengarah pada otomasi kantor, hambatan utamanya terletak pada kemampuan server yang tersedia.

Penerapan modernisasi budaya organisasi berupa penyempurnaan yang berkaitan dengan kebiasaan dan cara hidup dalam lingkungan kerja organisasi. Dalam praktik, hal tersebut berkaitan dengan pengembangan nilai yang dianut Pegawai Pajak melalui program Kanwil dan KPP percontohan dan pemahaman bahwa perbaikan-perbaikan yang dilakukan akan meningkatkan jumlah Wajib Pajak yang sadar pajak dan meningkatkan pembayaran pajaknya, penegakkan norma dengan penerapan Kode Etik Pegawai Direktorat Jenderal Pajak, pembaharuan iklim organisasi dengan konsep reward and punishment, serta peningkatan komitmen Pegawai Pajak terhadap tugasnya.

Konsep reward and punishment dalam program penerapan tata pemerintahan yang bersih dan berwibawa (good governance), diperlukan bagi perbaikan citra Direktorat Jenderal Pajak, penerapan kode etik dan adanya tambahan tunjangan berupa Tunjangan Kegiatan Tambahan (TKT), secara umum mendapat sambutan yang bagus.

Dari beberapa strategi yang diujikan dalam daftar pernyataan, pemberian pelayanan dengan mewujudkan customer satisfaction mendapatkan respon yang sangat bagus, hal ini dapat diartikan konsep pelayanan prima (service excellence) kepada Wajib Pajak sangat didukung oleh penerapan sistem administrasi perpajakan modern pada KPP Wajib Pajak. Umumnya Wajib Pajak setuju bahwa penyelenggaraan administrasi perpajakan secara modern merupakan perwujudan customer satisfaction dan good governance.

\section{KESIMPULAN}

Sistem administrasi perpajakan modern meliputi: (1) modernisasi struktur organisasi, (2) modernisasi prosedur organisasi, (3) modernisasi strategi organisasi, dan (4) modernisasi budaya organisasi berpangaruh secara simultan dan parsial terhadap kepatuhan Wajib Pajak di Lingkungan Kantor Pelayanan Pajak. Secara parsial modernisasi strategi organisasi memberikan kontribusi pengaruh yang terbesar (28,52\%), diikuti modernisasi prosedur organisasi $(19,41 \%)$, modernisasi struktur organisasi $(17,81 \%)$, dan modernisasi budaya organisasi memberikan pengaruh lemah, yaitu hanya 16,88\%. 
Besarnya pengaruh penerapan sistem administrasi perpajakan modern terhadap kepatuhan Wajib Pajak pada KPP di Lingkungan Kantor Pelayanan Pajak, dapat diartikan bahwa untuk meningkatkan kepatuhan Wajib Pajak, mengindikasikan perlunya dilakukan perbaikanperbaikan dalam administrasi perpajakan seperti melalui berbagai program dan kegiatan reformasi administrasi perpajakan jangka menengah yang digulirkan oleh Direktorat Jenderal Pajak sejak tahun 2001 yang terwujud dalam penerapan sistem administrasi perpajakan modern.

Besarnya pengaruh subvariabel modernisasi strategi organisasi dapat diartikan bahwa untuk meningkatkan kepatuhan Wajib Pajak, maka perlu dilakukan perbaikanperbaikan strategi organisasi dengan penerapan program kepuasan wajib pajak, perbaikan kepemimpinan, focus pada tujuan, dan peningkatan efisiensi dan efektifitas pegawai.

Besarnya pengaruh subvariabel modernisasi Prosedur organisasi dapat diartikan bahwa untuk meningkatkan kepatuhan Wajib Pajak, perlu dilakukan perbaikan prosedur organisasi dengan penerapan program kepuasan wajib pajak, pengembangan pelayanan prima, pengembangan dan peningkatan pelayanan, pemeriksaan dan penagihan yang ramah, serta penerapan Good Governance.

Besarnya pengaruh subvariabel modernisasi struktur organisasi dapat diartikan bahwa untuk meningkatkan kepatuhan Wajib Pajak, perlu dilakukan perbaikan struktur organisasi dengan penerapan program peningkatan pelayanan, pemeriksaan dan penagihan pada Kantor Pelayanan Pajak, penyederhanaan pemenuhan kewajiban perpajakan, serta pemanfaatan teknologi terkini.

Pengaruh subvariabel modernisasi budaya organisasi dan strategi organisasi lebih kecil dikarenakan budaya dan strategi organisasi tidak secara langsung berhubungan dengan kewajiban dan hak Wajib Pajak, tetapi lebih terkait internal organisasi.

\section{DAFTAR PUSTAKA}

Abimanyu, Anggito., 2001. Reformasi Perpajakan Perlu Dukungan Masyarakat. Badan Analisa Fiskal Departemen Keuangan. URL: http://www.fiskal.depkeu. go.id/beta/kolom1.asp? kolom1 1050000 sama dengan menggulang 15 Des 2004 22:29:59 GMT

Alink, Matthijs and Victor Van Kommer, 2009. The Dutch Approach: Description of the Dutch Tax Administration, Second Revised Edition, IBFD.

Bala, Swapan Kumar Bala dan Pallb Kumar Biswas, 2005. Tax Ombudsman in Bangladesh: An Analytical Review of the Regulatory Framework. The Cost and Management, Vol. 33 No. 6 NovemberDecember, pp. 27-40.

Bender, Lisa J., 2003. "India: Sing Announces Measures to Improve Tax Dispute Resolution", dalam Tax Notes International.

Bentley, Duncan. 2007. Taxpayers' Rights: Theory, Origin and Implementation, Kluwer Law International.

Boediono, B. 2003. Pelayanan Prima Perpajakan. Jakarta: Rineka Cipta.

Direktorat Jenderal Pajak RI, 2004. Buku Informasi Perpajakan. Jakarta: DJP- DepKeu RI.

Gillis, Malcolm. "Toward a Taxonomy for Tax Reform," Dalam Malcolm Gillis, peny., Tax Reform in Developing Countries, London: Duke University Press, 1989, hal. 7- 26.

Gunadi, 2003. "Keberhasilan Pajak Tergantung Partisipasi Masyarakat," Dalam Perspektif Baru, URL: $\quad$ http://www. perspektif.net/articles/ view.asp?id=431, 27 September.

Hamilton, Stuart. 2003. "Putting the Client First: The Emerging Coperation Copernican 
Revolution of Tax Administration", dalam Tax Notes International.

Ikhwan, Ali., 2004. Mengapa Ditjen Pajak Gagal

Perbaiki Citra? Investor Daily, URL: http://www.Investorindonesia.

com/news.html?id=1102646113, Jum'at, 10 Desember.

Ilyas, Wirawan B. dan Richard Burton, 2004. Hukum Pajak. Jakarta: Salemba Empat.

Keban, Yeremias T. 2004. Enam Dimensi Strategis Administrasi Publik, Konsep, Teori dan Isu. Yogyakarta: Gava Media.

Moliho, Oscar., 2004. "Limit on the Taxing Power of the Mexican Government". BIFD.

Nakazato, Minoru Mark Ramseyer, dan Yasutaka, 2004. "General Description Japan," dalam Comparative Income Taxation, Kluwer Law International.

Nasucha, Chaizi, 2004. Reformasi Administrasi Publik: Teori dan Praktik. Jakarta: Gramedia Widiasarana.

National Taxpayer Advocate, 2009. Report to Congress: Fiscal Year 2010 Objectives, 30 Juni.

Pakpahan, Robert. 2004. "Kantor Pelayanan Pajak Percontohan." Dalam buku Menuju Sistem dan Administrasi Perpajakan Berkelas Dunia: Studi Perpajakan di Indonesia dengan Inspirasi Pengalaman Jepang, ed. Robert Pakpahan dan toyomu Yuasa, Jakarta: JICA dan DJP, 2004.

Perry, Guillermo, dan John Walley. 2000. "Introduction." Dalam Guillermo Perry, John Walley, dan Gary McMahon. Peny., Fiscal Reform and Structural Change in Developing Countries, vol. 1. London: MacMillan Press. pp. 1-8.

Presiden Republik Indonesia. 2003. Instruksi Presiden Republik Indonesia Nomor 5 Tahun 2003 Tanggal 15 September 2003 Tentang Paket Kebijakan Ekonomi Menjelang dan Sesudah Berakhirnya Program Kerjasama dengan International Monetary Fund.
Purnomo, Hadi.2004. "Reformasi Administrasi Perpajakan," Dalam Heru Subyantoro dan Singgih Riphat, peny., Kebijakan Fiskal: Pemikiran, Konsep, dan Implementasi. Jakarta: Penerbit Buku Kompas, Februari 2004. hal. 218-233.

Raad, Kees van. 2004. General Description The Netherlands. Comparative Income Taxation, Kluwer Law International.

Republik Indonesia. 2005. Nota Keuangan dan Undang-undang Republik Indonesia Nomor 36 Tahun 2004 tentang Anggaran Pendapatan dan Belanja Negara Tahun Anggaran.

Romano, Carlo, 2004. "Private Rulling System in the EU Member States: A Comparative Survey", dalam European Taxation.

Scales, Sirena J. 2005. "Bangladesh: Parliament Approves Creation of Tax Ombudsman Post", dalam Tax Notes International.

Summer, Lawrence H., Johannes F. Linn, Shankar N. Acharya. Lesson of Tax Reform, Washington, D.C., U.S.A.: A World Bank Publication, 1991.

Suparno. 2000. Langkah-langkah Penulisan Artikel Ilmiah dalam Saukah, Ali dan Waseso, M.G. 2000. Menulis Artikel untuk Jurnal IImiah. Malang: UM Press.

Wibisono, Wahyu, 2004. "Rame-rame Menuju KPP WP Besar." Indonesia Tax Review. Volume III/Edisi 03/2003, pp. 4-10.

Widodo, Junaidi Eko. 2004. "Memanfaatkan Data Pemeriksaan untuk Menganalisa Kepatuhan Wajib Pajak." Dalam buku Menuju Sistem dan Administrasi Perpajakan Berkelas Dunia: Studi Perpajakan di Indonesia dengan Inspirasi Pengalaman Jepang, ed. Robert Pakpahan dan toyomu Yuasa, Jakarta: JICA dan DJP.

Yudkin, Leon., (1971). A Legal Structure of Effective Income Tax Administration, Cambridge: Harvard Law School.

Zauhar, Soesilo. 2002. Reformasi Administrasi Perpajakan, Konsep, Dimensi dan Strategi. Jakarta: Penerbit Bumi Aksara. 
